\title{
KEEFEKTIFAN ORGANISASI DINAS PEMBERDAYAAN MASYARAKAT DAN DESA KABUPATEN SUMBA BARAT, PROVINSI NUSA TENGGARA TIMUR
}

\author{
Daniel Umbu Sunga1, M. Irwan Tahir ${ }^{2}$ Irawan $^{3}$ \\ ${ }^{1}$ Pemerintah Daerah Kabupaten Sumba Barat \\ ${ }^{2,}{ }^{3}$ Institut Pemerintahan Dalam Negeri (IPDN) \\ Email: danielumbusunga14@gmail.com
}

\begin{abstract}
Abstrak
Penelitian ini bertujuan untuk menganalisis dan mengevaluasi keefektifan organisasi Dinas Pemberdayaan Masyarakat dan Desa Kabupaten Sumba Barat Provinsi Nusa Tenggara Timur. Penelitian ini melibatkan 43 informan (17 dari dinas PMD, 2 dari inspektorat, 2 dari Bappeda, 3 dari bagian organisasi, 4 dari kecamatan, 13 dari Desa, 1 dari PKK Kabupaten, dan 1 dari Tenaga Pendamping Profesional P3MD). Data dikumpulkan dengan menggunakan metode kualitatif (wawancara kualitatif dan pengumpulan dokumen kualitatif), dengan strategi penelitian studi kasus. Data yang terkumpul dianalisis menggunakan model interaktif. Pelaksanaan tugas dan fungsi Dinas PMD Kabupaten Sumba Barat Provinsi NTT belum efektif, dari 5 kriteria keefektifan yang dianalisis dan evaluasi ditemukan bahwa 4 kriteria (produksi, kepuasan, keadaptasian dan pengembangan) masih rendah, dan 1 kriteria lainnya yaitu efisiensi cukup tinggi, namun tidak memiliki korelasi positif dengan capaian kinerjanya.
\end{abstract}

Kata Kunci: Efektivitas Organisasi, Urusan Pemerintahan, Pemberdayaan Masyarakat dan Desa.

\section{Abstract}

This research aimed to analyze and evaluate the organizational effectiveness of Community and Village Empowerment office in West Sumba District, NTT Province. It involved 43 informants (17 from the PMD office, 2 from the inspectorate, 2 from Bappeda, 3 from the organization, 4 from the sub-district, 13 from the village, 1 from the District $P K K$, and 1 from the P3MD Professional Companion Staff). Data were collected using qualitative methods (qualitative interviews and qualitative document collection), with a case study research strategy. The collected data were analyzed using an interactive model. The implementation of the duties and functions of the PMD Office of West Sumba District, NTT Province has not been effective, of the 5 effectiveness criteria analyzed and evaluated, it was found that 4 criteria (production, satisfaction, adaptability and development) were still low, and 1 other criteria, namely efficiency was quite high, but did not have a positive correlation with the achievement of its performance.

Keywords: Organizational Effectiveness, Government Affairs, Community and Village Empowerment.

\section{A. PENDAHULUAN}

Negara Indonesia adalah negara kesatuan yang berbentuk republik, yang dibagi atas daerah-daerah provinsi dan daerah provinsi itu dibagi atas kabupaten dan kota. Pemerintah Negara Indonesia merupakan pemerintah nasional yang kemudian membentuk pemerintahan daerah pada tiap-tiap provinsi, kabupaten, dan kota yang berwenang untuk mengatur dan mengurus sendiri Urusan Pemerintahan menurut Asas Otonomi dan Tugas Pembantuan. 
Pemerintah Negara Indonesia dibentuk untuk mewujudkan empat tujuan bernegara yaitu pertama, untuk melindungi segenap bangsa Indonesia dan seluruh tumpah darah Indonesia, dan kedua, untuk memajukan kesejahteraan umum, ketiga, mencerdaskan kehidupan bangsa, dan keempat, ikut melaksanakan ketertiban dunia yang berdasarkan kemerdekaan, perdamaian abadi dan keadilan sosial, sebagaimana telah secara tegas diatur dalam Undang Undang Dasar Negara Republik Indonesia Tahun 1945. Amanat tersebut mengandung makna bahwa negara berkewajiban memenuhi kebutuhan setiap warga negara dan meningkatkan kesejahteraannya melalui suatu sistem pemerintahan yang mendukung terciptanya efektivitas dalam setiap penyelenggaraan urusan pemerintahan.

Untuk mempercepat terwujudnya tujuan Negara Indonesia, Pemerintah memberikan otonomi yang seluas-luasnya kepada Daerah Provinsi, Kabupaten, dan Kota berdasarkan prinsip negara kesatuan, guna meningkatkan pelayanan, pemberdayaan, dan peran serta masyarakat di masing-masing Daerah.

Desentralisasi merupakan salah satu asas dalam penyelenggaraan urusan pemerintahan yang mensyaratkan adanya pembagian urusan pemerintahan antara Pemerintah Pusat dengan Daerah provinsi dan Daerah kabupaten/kota, dimana ada urusan pemerintahan yang sepenuhnya menjadi kewenangan Pemerintah Pusat (absolut) maupun urusan pemerintahan (wajib dan pilihan) yang dibagi antara Pemerintah Pusat dan Daerah (konkuren) dengan skala atau ruang lingkup yang berbeda tetapi tetap memiliki hubungan (sinergi) satu dengan lainnya. Kebijakan Desentralisasi di Indonesia dewasa ini merupakan landasan normatif bagi penyelenggaraan pemerintahan di Daerah, termasuk perubahan kewenangan baik di tingkat pemerintah pusat, Daerah Provinsi maupun Daerah kabupaten/kota. Dengan Desentralisasi, Daerah memiliki kewenangan untuk menyelenggarakan Urusan Pemerintahan yang diserahkan oleh pemerintah Pusat. Dan untuk mendukung penyelenggaraan urusan pemerintahan yang menjadi kewenangannya, Daerah membentuk organisasi Perangkat Daerah yang efektif dan efisien sesuai karakter daerah dan kebutuhan masyarakatnya.

Perangkat Daerah atau yang biasa disebut juga dengan Birokrasi merupakan alat negara yang diharapkan mampu mendukung penyelenggaraan urusan pemerintahan Daerah yang menjadi kewenangannya secara maksimal dalam rangka mewujudkan kesejahteraan masyarakat dan kemandirian daerah sesuai tujuan Otonomi Daerah. Keefektifan organisasi Perangkat Daerah (birokrasi) dalam pelaksanaan tugas pokok dan fungsinya merupakan salah satu aspek yang menggambarkan tingkat keberhasilan dan kegagalan suatu Perangkat Daerah dalam mewujudkan tujuannya. Oleh karena itu sudah seharusnya birokrasi senantiasa berupaya untuk mengevaluasi, memperbaiki dan meningkatkan performa kerjanya sehingga birokrasi dapat menjadi solusi bagi setiap persoalan di tengah masyarakat.

Akan tetapi yang terjadi dewasa ini masyarakat lebih cenderung menilai birokrasi bukan lagi sebagai solusi tetapi justru menjadi bagian dari masalah bahkan sumber masalah di negara ini. Birokrasi yang berbelit belit, birokrasi yang menjadi momok/monster bagi masyarakatnya, birokrasi yang hanya melayani penguasa dan dirinya sendiri, birokrasi yang penuh dengan Korupsi, Kolusi dan Nepotisme, birokrasi yang lamban dalam melayani kebutuhan masyarakatnya dan juga tidak responsif dalam mengikuti berbagai dinamika perkembangan zaman. Persoalan tersebut semakin runyam ketika ditambah lagi dengan maraknya intervensi kepentingan politik dalam penataan perangkat daerah maupun penempatan para pejabat dan personilnya, yang bertujuan untuk mengakomodir berbagai kepentingan dan upaya balas jasa Kepala Daerah/Wakil Kepala Daerah kepada para pihak yang mendukung dalam proses pemilihan kepala daerah tanpa memperhatikan kompetensi aparatur. Jabatan dalam organisasi Perangkat Daerah terkesan menjadi bahan tawar menawar Kepala Daerah untuk mendapatkan dukungan politis. Hal tersebut sejalan dengan pandangan Prof. Djohermansyah Djohan (2019) yang menguraikan potret empirik Birokrasi Indonesia dalam prakteknya di era Otonomi Daerah yaitu "masih gemuknya struktur birokrasi pemerintahan 
(over seizing) dengan distribusi yang tidak merata serta anggaran belanja yang besar, kewenangan antar lembaga yang tumpang tindih (over lapping), belum tertibnya sistem, metode dan prosedur (Disorder), masih mengakarnya praktik KKN (pungli), masih lambannya pelayanan karena prosedur yang berbelit belit yang memakan banyak waktu dan biaya, tidak mengutamakan kualitas pelayanan, masih kuatnya pengaruh politik".

Begitu derasnya tuntutan masyarakat untuk pembaharuan sistem Birokrasi Pemerintah di Indonesia serta perbaikan berbagai aspek penyelenggaraan pemerintahan ke arah citizen/netizen oriented pasca era reformasi sampai saat ini, belum juga mampu menghasilkan kinerja pemerintahan yang baik sesuai dengan ekspektasi masyarakat. Oleh berbagai ahli, dari berbagai faktor penyebab lemahnya/rendahnya performa kerja birokrasi, salah satunya yaitu karena belum ditemukannya desain/model organisasi birokrasi pemerintah yang tepat fungsi dan tepat ukuran yang mampu menunjang penyelenggaraan tugas dan fungsi organisasi sesuai visi misi tujuan, sasaran dan strategi organisasi secara efektif dan efisien.

Kondisi tersebut sejalan dengan pandangan Tahir (2016:155) yang menyatakan bahwa regulasi yang mengatur pembentukan perangkat daerah selama ini menjadi acuan bagi daerah, ternyata belum mampu membangkitkan semangat otonomi yang memberikan kewenangan bagi daerah dalam rangka mengembangkan inovasi berdasarkan visi dan misinya. Pembentukan organisasi perangkat daerah selama ini didasarkan pada peraturan perundangundangan (rule driven organization). Demikian pula Martini, Tahir dan Khairi (2019:202) dalam penelitiannya mengungkapkan adanya kecenderungan saat ini ketidak sesuaian antara besaran struktur organisasi yang dibentuk dengan visi/misi organisasi. Hal ini akan menjadi penyebab penyelenggaraan Pemerintahan Daerah akan berjalan dalam jalur rutinitas belaka sehingga cenderung tidak mampu berdampak pada perubahan yang mendasar di daerah sesuai visi yang ditetapkan. Organisasi Perangkat Daerah yang dibentuk seringkali tidak memberikan kontribusi maksimal bagi pengembangan pembangunan Daerah.

Berbagai fenomena di lapangan terkait organisasi Pemerintahan Daerah dimaksud memberikan gambaran akan adanya pergeseran prinsip dari "structure follow function" yang secara tegas masih diusung oleh Undang Undang nomor 23 tahun 2014 ke "structure follow people" yang dapat menyebabkan tidak berfungsinya organisasi Perangkat Daerah secara efektif dan efisien.

Sesuai amanat Undang Undang nomor 23 tahun 2014 tentang pemerintahan daerah, Peraturan Pemerintah Nomor 18 tahun 2016 tentang Perangkat Daerah dan Peraturan Daerah Kabupaten Sumba Barat nomor 2 Tahun 2016 tentang Pembentukan dan Susunan Perangkat Daerah Kabupaten Sumba Barat, pada tahun 2016 Pemerintah Kabupaten Sumba Barat telah membentuk 51 (lima puluh satu) Perangkat Daerah dan unit kerja yang kemudian dilanjutkan dengan pelantikan pejabat struktural untuk mengisi jabatan struktural/personil pada perangkat daerah dimaksud.

Dalam 2 (dua) tahun perjalanannya ditemukan bahwa Perangkat Daerah maupun unit kerja yang telah dibentuk di kabupaten sumba barat pasca penerapan Peraturan Pemerintah Nomor 18 tahun 2016 tentang Perangkat Daerah belum sepenuhnya mampu menunjukkan kinerja sebagaimana yang diharapkan. Hal tersebut dapat dilihat dari hasil evaluasi Implementasi Sistem Akuntabilitas Kinerja Instansi Pemerintah (SAKIP) terhadap 5 (lima) komponen besar manajemen kinerja yang meliputi Perencanaan Kinerja, Pengukuran Kinerja, Pelaporan Kinerja, Evaluasi Internal, dan Pencapaian Sasaran/kinerja pada 51 (lima puluh satu) Perangkat Daerah dan unit kerja di kabupaten sumba barat yang dilaksanakan pada tahun 2019.

Hasil evaluasi SAKIP di atas diketahui bahwa dari 51 (lima puluh satu) perangkat daerah/unit kerja di kabupaten sumba barat, hanya 41 (empat puluh satu) perangkat daerah/unit kerja yang dapat dievaluasi dengan total nilai kumulatif sebesar 1.849,04 dengan rata-rata Perangkat Daerah sebesar 45,10 dengan kategori peringkat "C" (Kurang, Sistem dan tatanan kurang dapat diandalkan, memiliki sistem untuk manajemen kinerja tapi perlu banyak 
perbaikan minor dan perbaikan yang mendasar). Sementara 10 (sepuluh) perangkat daerah/unit kerja lainnya tidak dapat dievaluasi karena tidak dapat menyajikan dokumen-dokumen yang dibutuhkan baik itu Laporan Kinerja Instansi Pemerintah tahun 2018, Rencana Strategis (Renstra), Rencana Kerja (Renja), Rencana Kinerja Tahunan (RKT), Penetapan Kinerja (PK) serta dokumen terkait lainnya. Kondisi di atas menggambarkan belum optimalnya kinerja dari sebagian besar perangkat daerah yang dibentuk pasca penataan organisasi perangkat daerah sesuai Peraturan Pemerintah nomor 18 tahun 2016 di kabupaten sumba barat. Masih rendahnya rata-rata kinerja perangkat daerah dan unit kerja di kabupaten sumba barat, merupakan salah satu faktor yang dapat menghambat terwujudnya efektivitas penyelenggaraan urusan pemerintahan konkuren di daerah.

Salah satu urusan pemerintahan konkuren yang menjadi kewenangan Daerah Kabupaten dan sampai dengan saat ini masih menjadi isu penting yang cukup menyedot perhatian berbagai pihak baik dari lingkungan internal maupun eksternal pemerintahan adalah urusan pemberdayaan masyarakat dan Desa. Gencarnya kebijakan pemerintah pusat untuk meningkatkan kesejahteraan masyarakat melalui program pemberdayaan dan pembangunan dari tingkat Desa, dengan implikasi sumberdaya yang cukup besar baik itu dari Anggaran Pendapatan dan Belanja Negara maupun Anggaran Pendapatan dan Belanja Daerah Kabupaten, menuntut adanya komitmen dan sinergitas antara Pemerintah Pusat, Daerah maupun Desa baik itu dari aspek tata kerja, perencanaan, penganggaran maupun pelaksanaan program dan kegiatannya.

Sebagai satuan pemerintahan yang terdekat dengan Desa, Pemerintah Daerah Kabupaten memiliki peranan yang sangat penting dalam menyukseskan penyelenggaraan program dimaksud. Oleh karena itu keefektifan organisasi perangkat daerah yang menyelenggarakan urusan pemerintahan bidang Pemberdayaan Masyarakat dan Desa di tingkat Daerah Kabupaten merupakan suatu harapan sekaligus tuntutan yang harus menjadi perhatian Pemerintah Pusat maupun Daerah.

Adapun unsur pelaksana urusan pemerintahan bidang Pemberdayaan Masyarakat dan Desa di kabupaten sumba barat diwadahi dalam Dinas Daerah dengan nomenklatur Dinas Pemberdayaan Masyarakat dan Desa yang dalam pelaksanaan tugas dan fungsinya berpedoman pada Peraturan Bupati Sumba Barat nomor 25 tahun 2016 tentang Kedudukan, Susunan Organisasi, Tugas dan Fungsi serta Tata Kerja Dinas Pemberdayaan Masyarakat dan Desa Kabupaten Sumba Barat. Dinas tersebut bertugas membantu Kepala Daerah dalam menyelenggarakan urusan pemerintahan di Bidang Pemberdayaan Masyarakat dan Desa yang menjadi kewenangan daerah kabupaten yaitu penyelenggaraan penataan Desa, fasilitasi kerjasama antar desa dalam 1 (satu) Daerah Kabupaten, pembinaan dan pengawasan penyelenggaraan administrasi pemerintahan Desa, pemberdayaan lembaga kemasyarakatan yang bergerak di bidang PMD, dan lembaga adat tingkat Daerah kabupaten dan pemberdayaan masyarakat hukum adat yang masyarakat pelakunya hukum adat yang sama dalam daerah kabupaten, serta pemberdayaan lembaga kemasyarakatan dan lembaga adat tingkat Desa.

Dalam Rencana Strategis Dinas Pemberdayaan Masyarakat dan Desa Kabupaten Sumba Barat tahun 2016-2021, telah ditetapkan 16 sasaran yang merupakan penjabaran dari misi dan tujuan organisasi. Akan tetapi dalam pelaksanaan tugas dan fungsinya sejak bulan Januari tahun 2017 sampai dengan saat ini, Dinas Pemberdayaan Masyarakat dan Desa Kabupaten Sumba Barat belum dapat menunjukkan capaian kinerjanya. Data yang disajikan dalam Laporan Akuntabilitas Kinerja Instansi Pemerintah (LAKIP) Dinas Pemberdayaan Masyarakat dan Desa Tahun 2017 dan Tahun 2018 lebih cenderung ke arah penyampaian/pelaporan data realisasi belanja/capaian penyerapan berdasarkan belanja dan program/kegiatan.

Hasil evaluasi implementasi Sistem Akuntabilitas Kinerja Intansi Pemerintah (SAKIP) oleh Inspektorat atas dokumen Laporan Kinerja Instansi Pemerintah (LAKIP), Renstra 
Perangkat Daerah, Rencana Kinerja Tahunan (RKT), Dokumen Penetapan Kinerja, Rencana Aksi Perangkat Daerah serta dokumen pendukung lainnya pada Dinas Pemberdayaan Masyarakat dan Desa Kab. Sumba Barat tahun 2017 dan tahun 2018 sebagai berikut :

Tabel 1 Hasil Evaluasi Sistem Akuntabilitas Kinerja Instansi Pemerintah Dinas Pemberdayaan Masyarakat dan Desa Kabupaten Sumba Barat Tahun 2017 dan 2018

\begin{tabular}{|c|l|c|l|c|}
\hline \multirow{2}{*}{ No. } & \multicolumn{2}{|c|}{ Tahun 2017 } & \multicolumn{2}{c|}{ Tahun 2018 } \\
\cline { 2 - 5 } & \multicolumn{1}{|c|}{ Komponen } & Bobot (\%) & \multicolumn{1}{c|}{ Komponen } & Nilai \\
\hline 1 & Perencanaan Kinerja & 15,97 & Perencanaan Kinerja & 21,28 \\
\hline 2 & Pengukuran Kinerja & 2,19 & Pengukuran Kinerja & 4,06 \\
\hline 3 & Pelaporan Kinerja & 9,11 & Pelaporan Kinerja & 7,16 \\
\hline 4 & Evaluasi Internal & 0,50 & Evaluasi Internal & 0,50 \\
\hline 5 & $\begin{array}{l}\text { Pencapaian sasaran/kinerja } \\
\text { organisasi }\end{array}$ & 12,89 & $\begin{array}{l}\text { Pencapaian sasaran/kinerja } \\
\text { organisasi }\end{array}$ & 11,67 \\
\hline \multicolumn{2}{|c|}{ T O T A L } & $\mathbf{4 0 , 6 5}$ & T O T A L & $\mathbf{4 4 , 6 7}$ \\
\hline
\end{tabular}

Sumber: Laporan Hasil Evaluasi SAKIP Dinas PMD Kabupaten Sumba Barat Tahun 2017 dan 2018

Berdasarkan hasil evaluasi pada tabel 1 tersebut di atas, diketahui bahwa pada tahun 2017 Dinas Pemberdayaan Masyarakat dan Desa Kabupaten Sumba Barat memiliki bobot sebesar 40,65\% atau memperoleh predikat atau kategori C dengan interpretasi Kurang, Sistem dan tatanan kurang dapat diandalkan, memiliki sistem untuk manajemen kinerja tapi perlu banyak perbaikan minor dan perbaikan yang mendasar. Selanjutnya untuk tahun 2018 memperoleh nilai 44,67 dengan kategori C dan Interpretasi Kurang, Sistem dan tatanan kurang dapat diandalkan, perlu banyak perbaikan yang mendasar.

Sementara untuk target dan realisasi belanja tidak langusng maupun belanja langsung pada Dinas Pemberdayaan Masyarakat dan Desa Kabupaten Sumba Barat selama 2 (dua) tahun berturut turut (2017 dan 2018) cukup tinggi, sebagaimana dilihat pada tabel berikut:

Tabel 2 Target dan Realisasi Dana Berdasarkan Jenis Belanja Dinas Pemberdayaan Masyarakat dan Desa Kabupaten Sumba Barat Tahun 2017 dan 2018

\begin{tabular}{|c|l|c|c|c|c|c|c|}
\hline \multirow{2}{*}{ No } & \multicolumn{1}{|c|}{$\begin{array}{c}\text { Jenis } \\
\text { Belanja }\end{array}$} & $\begin{array}{c}\text { Target/Alokasi } \\
(\mathbf{R p})\end{array}$ & $\begin{array}{c}\text { Realisasi } \\
(\mathbf{R p})\end{array}$ & $\%$ & $\begin{array}{c}\text { Target/Alokasi } \\
(\mathbf{R p})\end{array}$ & $\begin{array}{c}\text { Realisasi } \\
(\mathbf{R p})\end{array}$ & $\%$ \\
\hline \multirow{2}{*}{1} & $\begin{array}{l}\text { Belanja } \\
\text { Tidak } \\
\text { Langsung }\end{array}$ & $1.505 .308 .230,-$ & $1.456 .856 .462,-$ & 96,78 & $1.596 .511 .820,-$ & $1.568 .477 .642,-$ & 98,24 \\
\hline 2 & $\begin{array}{l}\text { Belanja } \\
\text { Langsung }\end{array}$ & $7.573 .636 .506,-$ & $6.785 .114 .844,-$ & 89,59 & $4.175 .933 .334,-$ & $3.998 .694 .145,-$ & 95,76 \\
\hline
\end{tabular}

Sumber: Laporan Penyelenggaraan Pemerintahan Daerah (LPPD) Dinas PMD Kab. Sumba Barat Tahun 2017 dan Tahun 2018.

Dari data yang tersaji pada tabel 2 di atas, diketahui bahwa realisasi belanja (serapan anggaran) Dinas Pemberdayaan Masyarakat dan Desa Kabupaten Sumba Barat khususnya belanja langsung mengalami peningkatan dari tahun 2017 ke tahun 2018. Hal tersebut menunjukkan kondisi yang tidak sejalan dengan capaian kinerja Dinas Pemberdayaan Masyarakat dan Desa Kabupaten Sumba Barat pada tahun 2017 dan tahun 2018 yang memperoleh predikat/kategori $\mathrm{C}$ dengan interprestasi kurang. Meningkatnya realisasi belanja (serapan anggaran) Dinas Pemberdayaan Masyarakat dan Desa Kabupaten Sumba Barat di atas menunjukkan belum maksimalnya pemanfaatan anggaran di internal dinas dalam pencapaian tujuan dan sasarannya.

Kondisi tersebut semakin diperburuk dengan belum adanya pedoman nomenklatur khususnya di bidang Pemberdayaan Masyarakat dan Desa, yang tentu akan berdampak pada tidak maksimalnya sinkronisasi dan koordinasi dalam pelaksanaan tugas di internal maupun 
eksternal terkait urusan pemerintahan dimaksud. Ditambah lagi dengan belum adanya pembinaan dan pengendalian penataan Perangkat Daerah dari Gubernur sebagai wakil Pemerintah Pusat sampai saat ini, yang tentunya akan semakin menambah persoalan dalam penyelenggaraan urusan pemerintahan dimaksud.

Berbagai hal yang telah diuraikan di atas menunjukkan adanya gejala yang dapat menghambat terwujudnya pelaksanaan tugas dan fungsi Dinas Pemberdayaan Masyarakat dan Desa Kabupaten Sumba Barat yang efektif sebagaimana terkandung dalam harapan, prinsip serta asas asas pembentukan Perangkat Daerah yang diusung oleh Peraturan Pemerintah nomor 18 tahun 2016 tentang Perangkat Daerah. Dengan demikian salah satu tujuan dalam penelitian ini adalah untuk menganalisis dan mengevaluasi keefektifan organisasi Dinas Pemberdayaan Masyarakat dan Desa Kabupaten Sumba Barat Provinsi Nusa Tenggara Timur.

\section{B. METODE}

Dalam penelitian ini yang dijadikan obyek penelitian adalah Dinas Pemberdayaan Masyarakat dan Desa Kabupaten Sumba Barat Provinsi Nusa Tenggara Timur. Penelitian dilakukan menggunakan pendekatan kualitatif, melalui wawancara kualitatif dan pengumpulan dokumen kualitatif. Alasan peneliti menggunakan pendekatan kualitatif dengan maksud mencari makna dan upaya memahami bagaimana keefektifan organisasi Dinas Pemberdayaan Masyarakat dan Desa Kabupaten Sumba Barat Provinsi Nusa Tenggara Timur, sebagaimana pendapat Creswell (2018:4-5) bahwa penelitian kualitatif merupakan metode-metode untuk mengeksplorasi dan memahami makna yang-oleh sejumlah individu atau sekelompok orangdianggap berasal dari masalah sosial atau kemanusiaan. Proses penelitian kualitatif ini melibatkan upaya-upaya penting, seperti mengajukan pertanyaan-pertanyaan dan prosedurprosedur, mengumpulkan data yang spesifik dari para partisipan, menganalisis data secara induktif mulai dari tema-tema yang khusus ke tema-tema umum, dan menafsirkan makna data.

Adapun rancangan penelitian atau strategi penelitian yang digunakan adalah "studi kasus", yaitu rancangan penelitian yang ditemukan di banyak bidang, khususnya evaluasi, di mana peneliti mengembangkan analisis mendalam atas suatu kasus, seringkali program, peristiwa, aktivitas, proses, atau satu individu atau lebih (Stake \& Yin dalam Creswell, 2018:19). Dengan rancangan atau strategi penelitian ini peneliti menganalisis dan mengevaluasi secara mendalam bagaimana keefektifan organisasi Dinas Pemberdayaan Masyarakat dan Desa Kabupaten Sumba Barat Provinsi Nusa Tenggara Timur.

\section{HASIL DAN PEMBAHASAN}

Dalam menganalisis dan mengevaluasi keefektifan organisasi Dinas Pemberdayaan Masyarakat dan Desa Kabupaten Sumba Barat, peneliti menggunakan kelima kategori umum kriteria keefektifan yang dikemukakan oleh Gibson et al. (1985:34-35), yaitu Produksi, Efisiensi, Kepuasan, Kedaptasian, dan Pengembangan. Peneliti menggunakan kelima kategori umum tersebut di atas, karena secara khas dinyatakan dalam dimensi/ukuran waktu (pertimbangan waktu) baik itu jangka pendek untuk menunjukkan hasil tindakan dalam jangka waktu satu tahun atau kurang (Kepuasan, Efisiensi dan Produksi), maupun jangka menengah untuk menilai keefektifan organisasi dalam jangka waktu 5 tahun (perkembangan dan kadaptasian). Dan hal tersebut menurut peneliti dapat digunakan dalam rangka menilai keefektifan organisasi pemerintahan khususnya organisasi Perangkat Daerah dalam menjalankan tugas dan fungsinya karena sesuai dengan periode perencanaan tahunan dan lima tahunan Organisasi Perangkat Daerah. Selain itu juga kelima kategori umum dimaksud mencerminkan keseluruhan siklus masukan-proses-keluaran dan mencerminkan hubungan timbal balik antara organisasi dan lingkungan. 
Hasil penelitian dan pembahasan terkait dengan keefektifan organisasi Dinas Pemberdayaan Masyarakat dan Desa Kabupaten Sumba Barat Provinsi Nusa Tenggara Timur adalah sebagai berikut:

\section{Produksi}

Sebagai salah satu kriteria keefektifan, indikator produksi mengambarkan bagaimana capaian tujuan dan sasaran yang merupakan cerminan dari capaian kinerja sebuah organisasi. Berdasarkan hasil analisis dan evaluasi peneliti, diketahui bahwa dalam pelaksanaan tugas dan fungsinya selama tiga tahun berturut turut sejak tahun 2017, 2018 dan 2019, Produksi yang dihasilkan oleh Dinas PMD Kabupaten Sumba Barat (kemampuan untuk menghasilkan output dan outcome/capaian kinerja) tidak dapat diukur, karena dinas PMD belum memiliki indikator kinerja organisasi (IKU) yang terukur dan terintegrasi serta terarah yang mampu menggambarkan capaian terhadap tujuan, sasaran termasuk tugas dan fungsinya.

Tidak dapat digunakannya Indikator Kinerja Utama (IKU) yang telah ditetapkan dan digunakan oleh Dinas PMD Kabupaten Sumba Barat sejak tahun 2018 sampai saat ini untuk menilai/mengukur kinerja Dinas PMD secara keseluruhan baik sasarannya maupun targetnya, disebabkan karena dalam penyusunan Indikator Kinerja Utama (IKU)nya tidak dilakukan secara cermat dengan tidak memperhatikan keselarasan antar tingkatan unit organisasi, tidak melibatkan seluruh unsur internal maupun eksternal organisasi, tidak memperhatikan dokumen RPJMD, bidang kewenangan, tugas dan fungsi dan peran lainnya, serta berbagai ketentuan lainnya dalam regulasi terkait pemenuhan karakteristik indikator kinerja yang baik. Selain itu juga tidak pernah dilakukan evaluasi internal maupun eksternal atas dampak Indikator Kinerja Utama (IKU) terhadap kinerja organisasi. Kondisi tersebut pada akhirnya berdampak pada tidak jelasnya kontribusi dari kinerja dinas PMD selama tahun 2017-2019 pada capaian target Pemerintah Kabupaten Sumba Barat khusus dalam penyelenggaraan urusan pemerintahan di bidang Pemberdayaan Masyarakat dan Desa.

Menurut peneliti kriteria produksi yang dikemukakan oleh Gibson et al dapat menjadi salah satu kriteria yang turut mencerminkan keefektifan organisasi pemerintahan (perangkat daerah) namun bisa juga sebaliknya. Kriteria ini hanya dapat menjadi salah satu kriteria yang mencerminkan keefektifan organisasi perangkat daerah apabila keluaran utama organisasi perangkat daerah (Indikator Kinerja Utama PD) telah disusun sesuai kaidah penyusunan dan perumusan indikator kinerja organisasi yang baik dan terjabarkan secara rinci sampai ke kinerja individu dalam organisasi. Namun sebaliknya jika Indikator Kinerja Utama yang ditetapkan oleh perangkat daerah disusun dan dirumuskan tanpa mengacu pada kaidah penyusunan dan perumusan indikator kinerja organisasi yang baik, dalam artian IKU hanya disusun dan ditetapkan oleh perangkat daerah, tanpa ada penjabaran secara jelas/terukur untuk mencapai IKU tersebut, sehingga terkesan tidak representatif, maka kriteria Produksi ini dipastikan tidak akan turut mencerminkan keefektifan organisasi perangkat daerah yang sesungguhnya.

\section{Efisiensi}

Sebagai salah satu kriteria keefektifan, indikator efisiensi berorientasi pada minimalisasi penggunaan sumber daya untuk mencapai hasil kerja yang terbaik. Dalam penelitian yang dilakukan oleh Alimuddin \& Damis (2018:109-120) tentang efektifitas dan efisiensi pengelolaan angggaran Dinas Perindustrian dan Perdagangan Energi dan Sumber Daya Mineral Kabupaten Pinrang, efisiensi diukur dengan rasio antara output dengan input. Semakin besar ouput dibanding input, maka semakin tinggi tingkat efisiensi suatu organisasi. Nilai output yang digunakan dalam pengukuran ini adalah persentase perbandingan jumlah realisasi fisik yang dianggarkan. Sedangkan nilai input-nya merupakan persentase dari perbandingan input yang terealisasi dengan input yang dianggarkan. Rasio efisiensi dapat dikatakan efektif jika hasil perhitungannya menunjukkan nilai lebih dari 100\%. Semakin tinggi rasio maka semakin efisien. 
Berdasarkan hal tersebut dalam mengukur tingkat efisiensi pengelolaan anggaran pada Dinas PMD Kabupaten Sumba Barat, peneliti menggunakan rasio perbandingan dengan rumus sebagai berikut :

$$
\text { Rasio Efisiensi }=\frac{\text { Output }}{\text { Input }} \times 100 \%
$$

Rasio Efisiensi =

Output

Realisasi Anggaran/Anggaran

x $100 \%$

Efisiensi merupakan perbandingan antara hasil yang diperoleh dengan biaya yang dikeluarkan. Perhitungan rasio efisiensi terhadap seluruh program pada Dinas Pemberdayaan Masyarakat dan Desa Kabupaten Sumba Barat tahun 2017, 2018 dan 2019, dapat dilihat dalam tabel berikut:

Tabel 3 Pengukuran Rasio Efisiensi Terhadap Program Dinas PMD Kabupaten Sumba Barat Tahun 2017, 2018 dan 2019

\begin{tabular}{|c|c|c|c|c|c|c|c|c|c|}
\hline \multirow[b]{2}{*}{ PROGRAM } & \multicolumn{3}{|c|}{2017} & \multicolumn{3}{|c|}{2018} & \multicolumn{3}{|c|}{2019} \\
\hline & $\begin{array}{c}\text { Input } \\
(\%)\end{array}$ & $\begin{array}{c}\text { Output } \\
(\%)\end{array}$ & $\begin{array}{c}\text { Rasio } \\
\text { Efisiensi } \\
(\%)\end{array}$ & $\begin{array}{c}\text { Input } \\
(\%)\end{array}$ & $\begin{array}{c}\text { Output } \\
(\%)\end{array}$ & $\begin{array}{c}\text { Rasio } \\
\text { Efisiensi } \\
(\%) \\
\end{array}$ & $\begin{array}{c}\text { Input } \\
(\%)\end{array}$ & $\begin{array}{c}\text { Output } \\
(\%)\end{array}$ & $\begin{array}{c}\text { Rasio } \\
\text { Efisiensi } \\
(\%) \\
\end{array}$ \\
\hline $\begin{array}{ll}\text { a. Program Pelayanan Administrasi } \\
\text { Perkantoran }\end{array}$ & 88,46 & 72,37 & 81,81 & 97,29 & 100 & 102,79 & 97,65 & 99,04 & 101,42 \\
\hline $\begin{array}{l}\text { b. Program Peningkatan Sarana dan } \\
\text { Prasarana Aparatur }\end{array}$ & 97,95 & 100 & 102,09 & 95,98 & 100 & 104,19 & 96,44 & 100 & 103,69 \\
\hline $\begin{array}{l}\text { c. Program Peningkatan Disiplin } \\
\text { Aparatur }\end{array}$ & 100 & 100 & 100,00 & - & - & - & & - & - \\
\hline $\begin{array}{lll}\text { d. Program Peningkatan Kapasitas } \\
\text { Sumber Daya Aparatur }\end{array}$ & 46,52 & 100 & 214,96 & 68,91 & 100 & 145,12 & 100 & 100 & 100,00 \\
\hline $\begin{array}{ll}\text { e. } & \text { Program Peningkatan } \\
\text { Pengembangan Sistem Pelaporan } \\
\text { Capaian Kinerja dan Keuangan }\end{array}$ & 100 & 100 & 100,00 & 100 & 100 & 100,00 & 56,23 & 100 & 177,84 \\
\hline $\begin{array}{l}\text { f. Program Pameran/Promosi Hasil- } \\
\text { hasil Pembangunan }\end{array}$ & 100 & 100 & 100,00 & 100 & 100 & 100,00 & 100 & 100 & 100,00 \\
\hline $\begin{array}{llr}\text { g. } & \begin{array}{l}\text { Program } \\
\text { Keberdayaan } \\
\text { Perdesaan }\end{array} & \text { Peningkatan } \\
\text { Masyarakat }\end{array}$ & 94,19 & 78,29 & 83,12 & 92,80 & 100 & 107,76 & 90,71 & 100 & 110,24 \\
\hline $\begin{array}{l}\text { h. Program Pengembangan Lembaga } \\
\text { Ekonomi Pedesaan }\end{array}$ & 98,51 & 100 & 101,51 & 99,00 & 100 & 101,01 & 100 & 100 & 100,00 \\
\hline $\begin{array}{l}\text { i. Program Peningkatan Partisipasi } \\
\text { Masyarakat Dalam Membangun } \\
\text { Desa }\end{array}$ & 74,37 & 100 & 134,46 & 93,56 & 100 & 106,88 & 99,58 & 100 & 100,42 \\
\hline $\begin{array}{ll}\text { j. } & \text { Program Pembinaan dan Fasilitasi } \\
& \text { Pengelolaan Keuangan Desa }\end{array}$ & 71,95 & 100 & 138,99 & 97,53 & 100 & 102,53 & 98,00 & 100 & 102,04 \\
\hline $\begin{array}{l}\text { k. Program Peningkatan Kemitraan } \\
\text { dan Teknologi Perdesaan }\end{array}$ & 91,17 & 100 & 109,69 & 98,25 & 100 & 101,78 & 96,82 & 100 & 103,28 \\
\hline $\begin{array}{ll}\text { 1. Program Penataan Daerah } \\
\text { Otonomi Baru }\end{array}$ & 93,25 & 98 & 105,09 & 96,41 & 250 & 259,31 & 93,15 & 100 & 107,35 \\
\hline $\begin{array}{l}\text { m. Program Peningkatan Kapasitas } \\
\text { Aparatur Pemerintah Desa }\end{array}$ & - & - & - & 99,90 & 100 & 100,10 & 90,49 & 100 & 110,51 \\
\hline
\end{tabular}

Sumber: Dinas PMD Kabupaten Sumba Barat (2020).

Berdasarkan hasil analisis dan evaluasi peneliti terhadap kriteria Efisiensi di dinas PMD Kabupaten Sumba Barat selama tiga tahun berturut turut sejak tahun 2017, 2018 dan 2019 menunjukkan bahwa dinas PMD memiliki rasio efisiensi yang cukup tinggi. Namun tingginya rasio efisiensi dimaksud tidak berkorelasi positif dengan capaian kinerjanya yang 
dapat menggambarkan capaian tujuan dan sasaran pada Renstra Dinas PMD Kabupaten Sumba Barat.

Menurut peneliti kriteria efisiensi yang dikemukakan oleh Gibson et al ini hanya dapat digunakan untuk menilai keefektifan organisasi perangkat daerah, jika target program dan kegiatan dengan tujuan dan sasaran organisasi perangkat daerah telah selaras. Jika belum ada keselarasan target program dan kegiatan dengan tujuan dan sasaran perangkat daerah, maka hasil penilaian tingkat efisiensi organisasi hanya akan menggambarkan keuntungan sumberdaya yang digunakan, tanpa memperhatikan bagaimana kontribusinya terhadap capaian tujuan dan sasaran organisasi perangkat daerah. Hal tersebut sejalan dengan pendapat Aliansyah (2020) yang mengemukakan bahwa Efisiensi menganggap bahwa tujuan-tujuan yang benar telah ditentukan dan berusaha untuk mencari cara-cara yang paling baik untuk mencapai tujuan-tujuan tersebut.

\section{Kepuasan}

Sebagai salah satu kriteria keefektifan, indikator Kepuasan yang dikemukakan oleh Gibson et al berorientasi pada keberhasilan organisasi memenuhi kebutuhan pegawai. Demikian pula pandangan para ahli lainnya yang cenderung mendefenisikan kepuasan di internal organisasi sebagai salah satu kriteria bagi keefektifan organisasi. Sementara bagi organisasi pemerintahan sebagai unit yang melakukan pelayanan baik secara langsung maupun tidak langsung, peneliti berpandangan bahwa kriteria kepuasan sebagai salah satu ukuran yang menggambarkan keefektifan organisasi pemerintahan tidak saja hanya bergantung pada kondisi internal organisasi tetapi juga pada penilaian dari eksternal organisasi yang terkait langsung dengan pelaksanaan tugas dan fungsinya (kepuasan eksternal).

Dinas PMD dibentuk untuk membantu Kepala Daerah dan DPRD dalam menyelenggarakan urusan pemerintahan di bidang Pemberdayaan Masyarakat dan Desa, yang terbagi dalam empat sub urusan yaitu Penataan Desa, Kerja sama Desa, Administrasi Pemerintahan Desa, lembaga Kemasyarakatan, Lembaga Adat dan Masyarakat Hukum Adat. Oleh karena itu dalam menganalisa indikator kepuasan ini tidak saja hanya menggambarkan keberhasilan organisasi dalam memenuhi kebutuhan pegawai di internal perangkat daerah (kepuasan internal), tetapi menjadi penting juga untuk menganalisa sejauh mana keberhasilan Dinas PMD dalam memenuhi kebutuhan stakeholder terkait penyelenggaraan empat sub urusan pemerintahan di bidang pemberdayaan masyarakat dan Desa yang telah disebutkan di atas (kepuasan eksternal).

Berdasarkan hasil analisis dan evaluasi terhadap kepuasan internal, secara umum diketahui bahwa para pegawai di Dinas PMD belum merasa puas dengan cara kerja manajemen, karena berbagai kebutuhan pegawainya dalam melaksanakan tugas dan fungsinya belum sepenuhnya mampu dipenuhi oleh pimpinan Dinas, antara lain belum jelasnya tujuan, sasaran dan penilaian kerja, terbatasnya sarana prasarana di dinas PMD, sistem penggajian yang masih berbasis pangkat golongan dan masa kerja, belum diberlakukannya tunjangan kinerja dan tunjangan kemahalan, belum diterapkannya sistem reward and punishment, dan tidak adanya pengukuran tingkat kepuasan pegawai.

Berdasarkan hasil analisis dan evaluasi terhadap kepuasan eksternal, secara umum diketahui bahwa para Camat dan Kepala Desa di Kabupaten Sumba Barat belum merasa puas dengan kinerja Dinas PMD dalam menyelenggarakan urusan pemerintahan di bidang Pemberdayaan Masyarakat dan Desa. Hal itu dibuktikan dengan belum adanya upaya maksimal dan sistematis dari dinas PMD Kabupaten Sumba Barat dalam melaksanakan fungsi penyelenggaraan penataan Desa, pembinaan dan pengawasan penyelenggaraan administrasi pemerintahan Desa, fasilitasi kerjasama antar Desa di Kabupaten Sumba Barat, penyelenggaraan pemberdayaan lembaga kemasyarakatan di tingkat kabupaten maupun di Desa. 
Selain itu peneliti menemukan persoalan lain di luar belum puasnya pihak eksternal sebagaimana telah disebutkan di atas, yaitu belum pernah adanya upaya pemberdayaan masyarakat hukum adat maupun lembaga adat tingkat kabupaten dan tingkat desa oleh dinas PMD kabupaten sumba barat. Padahal pemberdayaan masyarakat hukum adat maupun lembaga adat tingkat kabupaten dan tingkat desa merupakan salah satu sub urusan pemerintahan di bidang pemberdayaan masyarakat dan Desa yang merupakan kewenangan daerah kabupaten. Hal tersebut tentu dapat berdampak pada minimnya peran masyarakat hukum adat dan lembaga adat baik di tingkat kabupaten maupun tingkat desa dalam memberdayakan, melestarikan, dan mengembangkan adat istiadat masyarakat Desa.

Pada akhirnya dari hasil analisis peneliti terhadap indikator kepuasan internal maupun eksternal dinas PMD Kabupaten Sumba Barat, dapat disimpulkan bahwa tingkat kepuasan terhadap kebijakan internal maupun eksternal dinas PMD Kabupaten Sumba Barat masih rendah. Hal tersebut disebabkan karena belum terpenuhinya berbagai kebutuhan yang mendukung operasional pelaksanaan tugas dan fungsi pegawai di internal dinas dan masih belum maksimalnya upaya yang dilakukan oleh Dinas PMD dalam memenuhi kebutuhan stakeholder terkait penyelenggaraan empat sub urusan pemerintahan di bidang pemberdayaan masyarakat dan Desa.

Menurut peneliti jika kriteria kepuasan yang dikemukakan oleh Gibson et al digunakan untuk menilai keefektifan organisasi Dinas Pemberdayaan Masyarakat dan Desa, maka hasil penilaian terhadap kriteria kepuasan hanya akan menggambarkan kepuasan di internal organisasi saja, tidak menggambarkan secara utuh bagaimana kinerja organisasinya. Padahal Dinas Pemberdayaan Masyarakat dan Desa dibentuk bukan hanya untuk melayani dirinya sendiri, tetapi juga untuk melayani berbagai pihak di eksternal organisasi terkait penyelenggaraan urusan pemerintahan di bidang pemberdayaan masyarakat dan Desa.

Hal tersebut sejalan dengan pandangan Rasyid (2007:11), yang menyatakan bahwa Pemerintahan tidaklah diadakan untuk melayani dirinya sendiri, tetapi untuk melayani masyarakat, menciptakan kondisi yang memungkinkan setiap anggota masyarakat mengembangkan kemampuan dan kreativitasnya demi mencapai kemajuan bersama. Demikian pula pandangan Hasan (2014:1.16) yang menyatakan bahwa "makna hakiki dari kata 'pemerintahan' adalah kemampuan memberikan pelayanan yang sebaik-baiknya kepada berbagai pihak."

Terhadap berbagai uraian di atas, Peneliti berpandangan bahwa untuk mendapatkan gambaran yang utuh terkait tingkat kepuasan suatu organisasi pemerintahan (perangkat daerah) khususnya Dinas Pemberdayaan Masyarakat dan Desa, penilaian terhadap kepuasan internal maupun eksternal organisasi merupakan 2 (dua) aspek penting yang harus dipertimbangkan. Oleh karena itu, dapat disimpulkan bahwa masih rendahnya indikator kepuasan di dinas PMD bukan saja disebabkan karena masih rendahnya tingkat kepuasan terhadap kebijakan di internal dinas, tetapi juga oleh karena masih rendahnya tingkat kepuasan dari eksternal Dinas PMD.

\section{Keadaptasian}

Sebagai salah satu kriteria keefektifan, indikator Keadaptasian berorientasi pada ketanggapan organisasi terhadap tuntutan perubahan. Keadaptasian ialah tingkat di mana organisasi dapat dan benar-benar tanggap terhadap perubahan internal dan eksternal. Dalam menganalisis dan mengevaluasi keadaptasian organisasi dinas PMD Kabupaten Sumba Barat Provinsi NTT, peneliti memedomani tiga unsur yaitu perencanaan strategis organisasi, budaya kerja aparatur, evaluasi internal dan eksternal.

Berdasarkan hasil analisis dan evaluasi, peneliti menemukan bahwa ternyata ketiga unsur yang mencerminkan tingkat keadaptasian organisasi, baik itu kebijakan strategis organisasi, budaya kerja aparatur maupun sistem evaluasi yang dibangun oleh Dinas PMD, belum berhasil membawa dinas PMD untuk mampu beradaptasi dengan berbagai perubahan dan tuntutan baik dari internal maupun eksternal organisasi. Hal tersebut disebabkan karena 
belum adanya upaya nyata dari Dinas PMD untuk membenahi kebijakan strategis organisasinya sesuai dengan arah pembangunan daerah sebagaimana tertuang dalam RPJMD Kabupaten Sumba Barat tahun 2016-2021, belum adanya upaya yang serius dan terukur dari Dinas PMD untuk membangun suatu budaya kerja dengan nilai nilai positif di lingkungan internal Dinas guna perbaikan dan peningkatan kinerja organisasi, bahkan untuk bagaimana memacu prestasi kerja aparatur, serta belum maksimalnya upaya Dinas PMD untuk melakukan evaluasi internal maupun eksternal serta menggunakannya sebagai sarana pembenahan dan peningkatan kinerja organisasi. Terkait hal tersebut Thoha (2015:206) telah mengingatkan bahwa dengan adanya tuntutan-tuntutan dari luar dan dalam itu, organisasi perlu dan secara terus-menerus harus menentukan sikap yang kondusif untuk menghadapi tantangan yang menggetarkan eksistensinya. Lebih lanjut ia mengatakan bahwa kemampuan adaptasi ini dirasakan amat perlu, terutama karena tuntutan-tuntutan itu sendiri terjadi perubahanperubahan yang berlangsung dengan cepat.

Belum maksimalnya kebijakan strategis organisasi, budaya kerja aparatur maupun sistem evaluasi yang dibangun di dinas PMD kabupaten sumba barat, mencerminkan belum maksimalnya kemampuan dinas PMD kabupaten sumba barat dalam menanggapi berbagai tuntutan perubahan baik dari internal maupun dengan eksternal organisasi (stakeholder).

\section{Pengembangan}

Sebagai salah satu kriteria keefektifan, indikator Pengembangan merupakan salah satu kriteria keefektifan yang mengukur tanggung jawab organisasi dalam memperbesar kapasitas dan potensinya untuk berkembang. Dalam menganalisis dan mengevaluasi indikator pengembangan pada organisasi dinas PMD Kabupaten Sumba Barat Provinsi NTT, peneliti memedomani tiga unsur yaitu peningkatan dan penguatan aparatur, pengembangan kemampuan manajerial pimpinan, langkah antisipasi organisasi terhadap perubahan lingkungan internal maupun eksternal.

Berdasarkan hasil analisis dan evaluasi, peneliti menemukan bahwa kebijakan dinas PMD Kabupaten Sumba Barat dalam upaya peningkatan dan penguatan kapasitas aparaturnya baik itu yang sifatnya struktural maupun fungsional dapat dikatakan belum maksimal. Lebih lanjut terkait upaya pengembangan kemampuan manajerial pimpinan di dinas PMD diketahui belum maksimal. Sementara langkah antisipasi dinas PMD terhadap perubahan lingkungan internal maupun eksternal juga belum dilakukan.

Terkait dengan temuan di atas, peneliti menemukan bahwa ternyata ada beberapa persoalan di internal maupun eksternal yang dapat mempengaruhi bahkan menghambat upaya dinas PMD untuk meningkatkan kapasitas/kemampuannya dalam menghadapi berbagai tuntutan lingkungan. Hal tersebut diketahui dari belum adanya kebijakan pengembangan kapasitas aparatur yang jelas dan terarah yang menggambarkan syarat kompetensi teknis seperti apa yang dibutuhkan dalam melaksanakan tugas dan fungsi sesuai bidangnya masing masing, sehingga menyebabkan anggaran yang dialokasikan dalam DPA dinas PMD untuk pengembangan kompetensi aparatur masih dianggarkan secara gelondongan. Selain itu juga terbatasnya kewenangan Dinas di mana Kepala Dinas tidak dapat mengelola organisasi perangkat daerah yang dipimpinnya secara mandiri dengan kewenangan yang memadai dalam manajemen ASN di unit organisasinya, terbatasnya alokasi anggaran yang diperoleh, adanya perubahan kebijakan di tingkat kabupaten, belum adanya kebijakan sebagai langkah antisipasi organisasi terhadap berbagai perubahan yang mungkin terjadi, serta kurang maksimalnya dukungan perangkat daerah terkait baik itu dari unsur staf, unsur penunjang maupun unsur pelaksana di kabupaten sumba barat yang mampu menunjang peningkatan kapasitas/kemampuan organisasi Dinas PMD.

Terkait dengan hal tersebut, Thoha (2015:206) telah mengingatkan bahwa dalam perkembangannya, organisasi pasti mengalami berbagai tuntutan eksternal maupun internal. Oleh karena itu organisasi harus menentukan sikap yang tepat untuk menjaga eksistensinya. 
Organisasi harus meningkatkan kemampuannya sehingga mampu mengimbangi berbagai tuntutan perubahan tersebut. Untuk itu sangat dibutuhkan suatu upaya untuk membina dan mengembangkan organisasi.

Terbatasnya kewenangan kepala perangkat daerah dalam mengelola secara mandiri organisasi yang dipimpinnya menyebabkan upaya pengembangan bagi organisasi di lingkungan pemerintahan Daerah tidak saja berada dalam jangkauan kebijakan di internal perangkat daerah, tetapi juga bergantung pada dukungan kebijakan dari perangkat daerah lainnya yaitu Badan Kepegawaian, Pendidikan dan Pelatihan, maupun Badan Perencanaan Pembangunan Daerah yang merupakan bagian dari unsur penunjang dalam penyelenggaraan urusan pemerintahan yang menjadi kewenangan Daerah.

Oleh karena itu, dari berbagai hasil analisis terhadap indikator pengembangan dapat disimpulkan bahwa upaya pengembangan kapasitas maupun potensi organisasi Dinas PMD kabupaten sumba barat belum maksimal, dan kondisi tersebut disebabkan bukan saja karena belum optimalnya upaya yang dilakukan dari internal dinas, tetapi juga dipengaruhi dari faktor eksternalnya.

\section{KESIMPULAN}

Dinas Pemberdayaan Masyarakat dan Desa Kabupaten Sumba Barat Provinsi NTT belum dapat melaksanakan tugas dan fungsinya secara efektif. Hal tersebut diketahui dari hasil analisa dan evaluasi terhadap 5 (lima) kriteria keefektifan organisasi di Dinas Pemberdayaan Masyarakat dan Desa Kabupaten Sumba Barat Provinsi NTT yang menunjukkan bahwa dari aspek produksi, capaian kinerja Dinas PMD Kabupaten Sumba Barat (kemampuan untuk menghasilkan output dan outcome) selama tiga tahun berturut turut sejak tahun 2017, 2018 dan 2019 tidak dapat diukur, karena belum adanya Indikator Kinerja Utama (IKU) organisasi yang jelas, representatif dan terukur. Demikian pula dari aspek kepuasan, dimana ditemukan bahwa tingkat kepuasan terhadap kebijakan internal maupun eksternal Dinas PMD masih rendah. Selanjutnya dari aspek keadaptasian, peneliti menemukan bahwa kemampuan Dinas PMD dalam menanggapi berbagai tuntutan perubahan baik dari internal organisasi maupun dengan stakeholder masih belum maksimal. Lebih lanjut dari aspek pengembangan, ditemukan bahwa upaya Dinas PMD dalam meningkatkan kapasitas maupun potensinya dalam menyelenggarakan tugas dan fungsinya juga masih belum maksimal. Berbeda dengan empat aspek tersebut di atas, dari hasil analisis terhadap dari aspek efisiensi, peneliti menemukan bahwa dalam pelaksanaan tugas dan fungsinya selama tiga tahun berturut turut sejak tahun 2017, 2018 dan 2019, dinas PMD kabupaten Sumba Barat telah mengelola anggaran dengan cukup efisien. Hal tersebut dibuktikan dengan cukup tingginya rasio efisiensi selama tiga tahun berturut turut, namun tingginya rasio efisiensi tersebut tidak berkorelasi positif dengan capaian kinerjanya.

Belum efektifnya pelaksanaan tugas dan fungsi Dinas PMD Kabupaten Sumba Barat sejak pembentukannya pada akhir tahun 2016 sampai dengan saat ini diharapkan menjadi perhatian pemerintah daerah kabupaten Sumba Barat dan seluruh aparatur yang bertugas di dinas PMD pada khususnya agar kiranya dapat membenahi dokumen perencanaan strategis dinas, memperbaiki kebijakan pengelolaan sumberdaya yang berorientasi pada tujuan dan sasaran, meningkatkan kemampuan organisasi dalam menganggapi berbagai tuntutan perubahan baik dari internal maupun eksternal organisasi, serta membenahi kebijakan terkait pengembangan kapasitas maupun potensi organisasi perangkat daerah. Dibutuhkan suatu langkah nyata untuk memperbaiki berbagai kelemahan yang masih terjadi sehingga dapat terwujud peningkatan kinerja yang mengarah pada terpenuhinya kelima kriteria keefektifan organisasi baik itu dari aspek produksi, efisiensi, kepuasan, keadaptasian, maupun pengembangannya. Kesempatan yang tersedia untuk membenahi berbagai aspek dimaksud pada tahun ini sangat tepat, karena pada tahun 2021 ini akan dimulai proses penyusunan 
RPJMD Kabupaten Sumba Barat yang baru, dimana seluruh Perangkat Daerah akan menyusun ulang dokumen perencanaan strategis organisasinya, dan kesempatan ini akan menjadi awal yang sangat menentukan bagi Dinas PMD Kabupaten Sumba Barat untuk mewujudkan keefektifan organisasinya.

\section{DAFTAR PUSTAKA}

Aliansyah, M. (2018). Efisiensi dan Efektivitas Pelayanan di Sektor Pemerintahan. Retrieved from

https://www.kompasiana.com/muhammadaliansyah/5c0a45a2ab12ae77084c1867/efis iensi-dan-efektivitas-pelayanan-di-sektor-pemerintahan.

Alimuddin, F., \& Damis, H. (2018). Analisis Efektifitas dan Efisiensi Pengelolaan Anggaran Dinas Perindustrian Perdagangan Energi dan Sumber Daya Mineral Kabupaten Pinrang. PARADOKS: Jurnal Ilmu Ekonomi, 1(1), 108-120.

Creswell, J. W. (2018). Research Design: Pendekatan Metode Kualitatif, Kuantitatif, dan Campuran. Yogyakarta: Pustaka Pelajar. Yogyakarta.

Djohan, D. (2019). Materi Kuliah Teori dan Terapan Politik Kontemporer. Jakarta: Program Pascasarjana MTSP IPDN.

Dokumen Pelaksanaan Perubahan Anggaran (DPPA) Dinas PMD Kabupaten Sumba Barat Tahun 2017.

Dokumen Pelaksanaan Perubahan Anggaran (DPPA) Dinas PMD Kabupaten Sumba Barat Tahun 2018.

Dokumen Pelaksanaan Perubahan Anggaran (DPPA) Dinas PMD Kabupaten Sumba Barat Tahun 2019.

Gibson, J. L., Ivancevich Jhon, M., \& Donnelly James, H. (1985). Organisasi (Prilaku, Struktur, Proses). Jakarta: Erlangga.

Hasan, E. (2014). Komunikasi Pemerintahan. Banten: Universitas Terbuka.

Keputusan Kepala Dinas PMD Kabupaten Sumba Barat nomor : DPMD.410/509/53.12/9/2018 tentang Indikator Kinerja Utama di lingkungan Dinas PMD Kabupaten Sumba Barat Tahun 2016-2021.

Laporan Akuntabilitas Kinerja Instansi Pemerintah (LAKIP) Dinas PMD Kabupaten Sumba Barat Tahun 2017.

Laporan Akuntabilitas Kinerja Instansi Pemerintah (LAKIP) Dinas PMD Kabupaten Sumba Barat Tahun 2018.

Laporan Penyelenggaraan Pemerintahan Daerah (LPPD) Dinas PMD Kabupaten Sumba Barat Tahun 2017.

Laporan Penyelenggaraan Pemerintahan Daerah (LPPD) Dinas PMD Kabupaten Sumba Barat Tahun 2018.

Laporan Penyelenggaraan Pemerintahan Daerah (LPPD) Dinas PMD Kabupaten Sumba Barat Tahun 2019.

Laporan Hasil Evaluasi (LHE) Sistem Akuntabilitas Kinerja Instansi Pemerintah Dinas Pemberdayaan Masyarakat dan Desa Kabupaten Sumba Barat Tahun 2017.

Laporan Kompilasi Hasil Evaluasi Implementasi SAKIP Perangkat Daerah Kabupaten Sumba Barat Tahun 2018.

Martini A., Tahir, M. I. dan Khairi, H. (2019). Aplikasi Model Organisasi Pada Struktur Organisasi Perangkat Daerah. Jurnal Ilmu Ilmu Sosial dan Humaniora, 21(2).

Peraturan Pemerintah Nomor 18 tahun 2016 tentang Perangkat Daerah sebagimana telah diubah dengan Peraturan Pemerintah Nomor 72 tahun 2019 tentang Perubahan Atas Peraturan Pemerintah Nomor 18 tahun 2016 tentang Perangkat Daerah. 
Peraturan Daerah Kabupaten Sumba Barat nomor 2 tahun 2016 tentang Pembentukan dan Susunan Perangkat Daerah Kabupaten Sumba Barat.

Peraturan Bupati Sumba Barat nomor 25 tahun 2016 tentang Kedudukan, Susunan Organisasi, Tugas dan Fungsi serta Tata Kerja Dinas Pemberdayaan Masyarakat dan Desa Kabupaten Sumba Barat.

Rasyid, M. R. (2007). Makna Pemerintahan: Tinjauan dari Segi Etika dan Kepemimpinan. Jakarta: Mutiara Sumber Widya.

Tahir, M I. (2016). Analisis Kritis terhadap Peraturan Pemerintah Nomor 18 Tahun 2016 tentang Perangkat Daerah. Jurnal Pendayagunaan Aparatur Negara, Edisi 6, Tahun VI.

Thoha, M. (2015). Ilmu Administrasi Publik Kontemporer. Jakarta: Prenada Media Group.

Undang Undang Nomor 23 tahun 2014 tentang Pemerintahan Daerah. 